\title{
Effect of Video Information on Anxiety Level in Women Undergoing Endometrial Biopsy
}

\section{Endometriyal Biyopsi Yapılan Kadınlarda Video ile Bilgilendirmenin Anksiyete Düzeyine Etkisi}

\author{
Zekiye Soykan Sert ${ }^{1}$ \\ 'Department of Gynecology and Obsterics, Aksaray University Education and Research Hospital, Aksaray, Turkey
}

\begin{abstract}
Aim: We evaluated the impact of video information in addition to routinely applied verbal and written information on satisfaction and anxiety levels in women who are planned to undergo endometrial biopsy.

Material and Method: A total of 84 patients who underwent endometrial biopsy were included in this prospective study. Patients were divided into "video group" and "no video group" based on written and/or visual information provided. State anxiety scale (STAI-S) and the anxiety (HADS-A) subscale of the Hospital Anxiety and Depression Scale (HADS) were used to measure the anxiety levels of patients. Both groups were given standard verbal and written information about the biopsy. In addition, patients in the video group watched video information. Both groups were reevaluated with STAI-S and HADS-A afterward. Patient satisfaction was evaluated using a Likert-type scale and the pain score during biopsy was evaluated using visual analog scale (VAS).
\end{abstract}

Results: Pre-information STAI-S and HADS-A scores were high in both groups (STAI-S $\geq 42$ and HADS-A $\geq 11$ ). No significant difference was observed between the post-information and preinformation STAI-S and HADS-A scores of the no video group ( $p$ $>0.05$ ). However, a significant decrease was observed in postinformation STAI-S and HADS-A scores in the video group ( $\mathrm{p} \leq$ 0.001 ). Further, no significant difference was observed between the two groups in terms of VAS scores $(p=0.20)$. Satisfaction was higher in the group receiving video information $(p=0.001)$.

Conclusions: Endometrial biopsy can cause stress and increase patient anxiety. Video information reduces patient anxiety and increases satisfaction.

Keyword: Endometrial biopsy, anxiety, video information, StateTrait Anxiety Inventory, Hospital Anxiety and Depression Scale
Öz

Amaç: Endometrial biopsi yapılması planlanan kadınlarda, rutin olarak uygulanan sözel ve yazılı bilgilendirmeye ek olarak video ile bilgilendirmenin memnuniyet ve anksiyete düzeyine etkisini değerlendirdik.

Gereç ve Yöntem: Bu prospektif çalışmaya endometrial biyopsi uygulanan toplam 84 hasta dahil edildi. Hastalar, uygulanan yazılı ve/ veya görsel bilgilendirmeye göre "video grup" ve "no video grup" olarak 2' ye ayrıldı. Hastaların anksiyete düzeylerini ölçmek için durumluk anksiyete ölçeği (STAI-S) ve Hospital Anxiety and Depression Scale(HADS) ölçeğinin anksiyete (HADS-A) alt ölçeği kullanıldı. Her iki gruba, biyopsi uygulama süreci hakkında standart sözlü veyazılı bilgiler verildi. Ek olarak video grubundaki hastalara bilgilendirme videosu izletildi. Her iki grup bilgilendirme sonrası STAI-S ve HADS-A ile tekrar değerlendirildi. Hastaların memnuniyeti likert tipi ölçek ile, biyopsi sırasındaki ağrı skoru ise VAS (Visual Analog Scale) ile değerlendirildi.

Bulgular: Pre-information STAI-S ve HADS-A skoru her iki grupta yüksek düzeyde saptandı (STAI-S $\geq 42$, HADS-A $\geq 11$ ). No video grubunun post-information STAI-S ve HADS-A skoru, preinformation anksiyete skorlarına göre istatiksel olarak anlamlı farklılık saptanmadı(p>0.05). Ancak video grubundaki post-information STAI-S ve HADS-A skorlarında anlamlı bir azalma saptandı $(p=<0.001)$. I ki grup arasında VAS skorları açısından anlamlı fark yoktu( $p=0.20)$. Video ile bilgilendirme yapılan grupta memnuniyet daha yüksekti $(p=0.001)$

Sonuç: Endometrial biyopsi yapmak strese neden olabilir ve hastaların anksiyetesini artırabilir. Video ile bilgilendirme hasta kaygısını azaltır, memnuniyetini arttırır.

Anahtar Kelimeler: Endometrial biyopsi, anksiyete, video ile bilgilendirme, Durumluk Sürekli Kaygı Envanteri, Hastane Anksiyete ve Depresyon Ölçeği

Corresponding (Illetişim): Zekiye Soykan Sert, Department of Gynecology and Obsterics, Aksaray University Education and Research Hospital, Aksaray, Turkey

E-mail (E-posta): zekiyesoykan@hotmail.com

Received (Geliş Tarihi): 19.07.2020 Accepted (Kabul Tarihi): 13.09.2020 


\section{INTRODUCTION}

Today, endometrial biopsy with pipelle is often used and recommended in the diagnosis of endometrial pathologies in outpatients. ${ }^{[1]}$ Although pipelle biopsy is known as a painless or slightly painful procedure compared with conventional methods, approximately half of the patients experience varying degrees of pain during the procedure. ${ }^{[2]}$ Furthermore, this procedure can be stressful for patients, and invasive medical practices such as endometrial biopsy may increase patient anxiety. ${ }^{[3,4]}$ Studies in the literature have shown that patients were concerned about the diagnosis and treatment procedures to be applied and informing patients was necessary. ${ }^{[5]}$

Various preoperative informing methods are used to reduce patient anxiety. The most common method is written information form, but all the patients may not be literate, understand the given information form, or remember comprehensive information. Therefore, some studies have shown that visual information methods are more effective in reducing patient anxiety levels rather than written information methods. ${ }^{[6,7]}$ Contrary to these studies, there is also an opinion that visual information is not effective in reducing anxiety levels because of the increasing use of the internet, resulting in people having more knowledge about their own health or diseases. ${ }^{[8]}$

Patients with vaginal bleeding are already anxious when referring to physicians, and when it is indicated that a biopsy is required for diagnosis, patient anxiety increases because of the procedure itself or the possibility of negative results. Although endometrial biopsy is a frequently performed gynecological procedure, potential stress before and during the procedure has been ignored. Therefore, there is a requirement for further studies on state anxiety before endometrial biopsy. This study aimed to compare the effect of video information in addition to routinely applied verbal and written information on anxiety level in women who are planned to undergo endometrial biopsy with pipelle. This study also aimed to determine the effect of video information on patient satisfaction and pain level.

\section{MATERIAL AND METHOD}

\section{Participants and procedure}

This prospective study was conducted between August 1, 2019 and February 29, 2020 in the Gynecology and Obstetrics clinic of our hospital, and included 84 patients aged 25 and older with endometrial biopsy indication. The study protocol was approved by the ethics committee of the Faculty of Medicine of Ahi Evran University (protocol number: 2019-12/139).

Patients with psychiatric disease, vision and hearing problems, additional disease that can cause anxiety, patients undergoing treatment with antidepressant drugs, refusing to fill out the forms, without the mental capacity to fill out the form, illiterate patients, patients with incomplete or improperly filled surveys, patients with abundant vaginal bleeding, and previous history of endometrial biopsy were excluded from the study.
All patients were informed about the endometrial biopsy procedure and were asked to participate in the study prior to endometrial biopsy. Informed consent was received from patients who agreed to participate in the study. State-Trait Anxiety Inventory (STAI) and Hospital Anxiety and Depression Scale (HADS) were used to measure anxiety levels. Before informing the patients, anxiety levels were evaluated using the state anxiety scale (pre-information STAI-S) and the anxiety subscale of the HADS scale (pre-information HADS-A). Patients were divided into "video group" and "no video group" based on written and/or visual information provided. Both groups were provided standard verbal and written information about endometrial biopsy with pipelle. In addition, patients in the video group watched a 5-min informational video about endometrial biopsy. The post-information anxiety levels of both groups were evaluated using STAI-S (Post-information) and HADS-A (Post-information).

The interviews conducted by the researcher with all patients were conducted under the same environmental conditions. To collect reliable data from all patients, no premedication (including sedative drugs, local anesthetics, or other drugs) was given before informing the patients. Endometrial pipelle biopsy was performed by a doctor who was blinded to the randomization of the patients and types of information provided. Visual analog scale (VAS) was used to assess pain in both groups during biopsy. Satisfaction level after biopsy was evaluated with a Likert-type scale. The study design is shown in Figure 1.

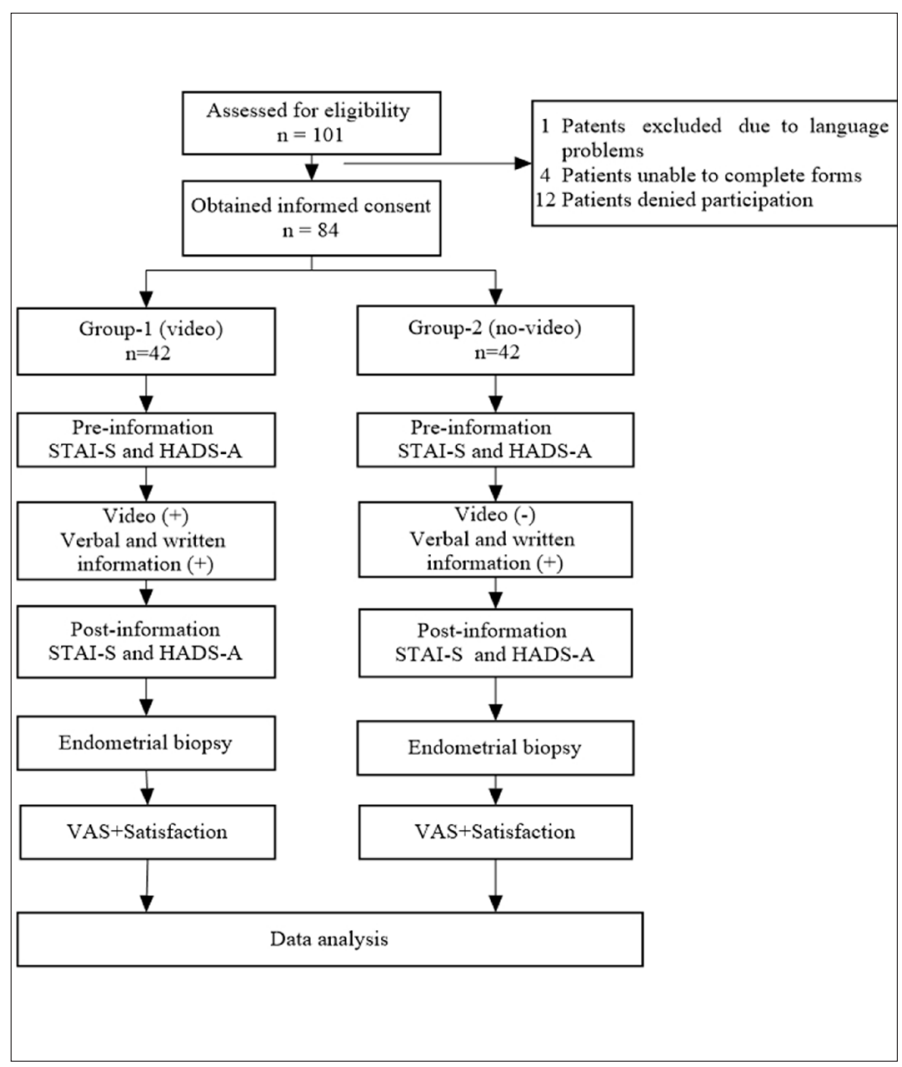

Figure1. Flow chart of study selection process 


\section{Video information}

The video was watched in the intervention room with the help of tablets. The 5-min tutorial video developed for this study included the following topics: 1) what is endometrial biopsy and why it is done?, 2) how is pipelle applied?, 3) the estimated duration of the procedure, and 4) what will happen after the procedure?

\section{Questionnaire}

Anxiety levels of patients before endometrial pipelle biopsy were evaluated using STAI-S and HADS-A. STAI: State anxiety (STAI-S) scale aims to measure anxiety at a given time, whereas the trait anxiety (STAI-T) scale measures long-term anxiety levels. STAI-S consists of 20 items. It is a four-point Likert-type scale and items are scored between 1 and 4, either negative or positive depending on the selected option. Fifty points are added to the total score obtained. The highest score that can be obtained from the scale is 80 , and the lowest score is 20. Further, $20-35$ points indicate little anxiety, $36-41$ points indicate moderate anxiety, and $42-80$ points indicate high level of anxiety. ${ }^{[9,10]}$ HADS: This scale consists of 14 items. Seven items evaluate the symptoms anxiety (HAD-A) and seven items evaluate the symptoms of depression (HAD-D). Odd numbered items investigate anxiety and even numbered items investigate depression. It is a four-point Likert-type scale, and the items are scored between 0 and 3 . The scoring of each item on the scale is different. The lowest score patients can get is 0 and the highest score is 21. The cutoff value of the anxiety subscale of the Turkish form of HAD was found to be 10. Accordingly, scores above 10 are evaluated as at risk. ${ }^{[11,12]}$ VAS: The level of pain in patients after biopsy was assessed using VAS. On this scale, 0 means that there is no pain at all, and 10 means that there is very severe pain. Satisfaction level: Post-intervention level of satisfaction for types of information was evaluated with a five-point Likert-type scale. Level of Satisfaction; 1-5 point, 1: Not at all satisfied, 5: Extremely satisfied.

\section{Statistical analysis}

According to the power analysis determined by reviewing similar studies, with a power of $80 \%(\beta=0.20)$, confidence interval of $95 \%$ and error margin of $\alpha=0.05$, the number of individuals to be included in the study was found to be $84 .{ }^{[13]}$ Data were analyzed using Statistical Package for Social Sciences (SPSS) version 15.0 (SPSS Inc., Chicago, IL, USA). When evaluating the study data, descriptive statistical methods (percentage, median, mean, and standard deviation) were used. For intergroup comparisons, chi-squared test was used for categorical variables, student's t-test was used for continuous variables, Mann-Whitney U-test or KruskalWallis variance analysis was used for non-normally distributed continuous variables and sequential variables. Results were evaluated at $95 \%$ confidence interval. $P<0.05$ was considered statistically significant.

\section{RESULTS}

The mean age of the patients who participated in the study was $45.6 \pm 8$ years in the video group and $44.2 \pm 9$ years in the no video group. There was no significant difference between the groups in terms of age $(p=0.50)$. In the present study, there was no statistically significant relationship between the groups in terms of education level $(p=0.43)$. Demographic characteristics and data of patients participating in the study are shown in Table 1. There was no statistically significant difference between the groups in terms of pre-information STAI-S scores and HADS-A scores (video group; $\mathrm{p}=0.76$, no video group; $\mathrm{p}=0.62$ ) and high anxiety levels were detected in both groups (STAI-S $\geq 42$ and HADS-A $\geq 11$ ). Post-information STAI-S and HADS-A scores were lower in the video group (39.1 \pm 4.7 and $9.7 \pm 2.2$, respectively). There was a statistically significant difference in post-information STAI-S and HADS-A scores between the groups ( $p=0.02$ and $p=0.01$, respectively). There was no statistically significant difference between the groups in terms of VAS scores $(p=0.20)$. Satisfaction was generally high in the video group and a significant difference was found between the groups $(p=0.001)$. There was no statistically significant difference between anxiety levels in terms of the educational status of the patients (Table 2). There was no significant difference between post-information and pre-information STAI-S and HADS-A scores in the no video group ( $p=0.32$ and $p=0.13$, respectively), whereas a significant decrease was found in post-information STAI-S and HADS-A scores in the video group ( $p \leq 0.001$ and $p \leq 0.001$, respectively) (Table 3 ).

\begin{tabular}{|c|c|c|c|}
\hline & $\begin{array}{l}\text { Video } \\
\text { group } \\
(n=42)\end{array}$ & $\begin{array}{l}\text { No video } \\
\text { group } \\
(n=42)\end{array}$ & p-value \\
\hline Age (years)" & $45.6 \pm 8$ & $44.2 \pm 9$ & 0.50 \\
\hline Educational level & \multirow[b]{2}{*}{31 (47.7\%) } & & 0.43 \\
\hline$\leq$ High school & & $34(52.3 \%)$ & \\
\hline$\geq$ University & $11(57.9 \%)$ & $8(42.1 \%)$ & \\
\hline STAI-State score(Pre-information)ף & $42.4 \pm 5.6$ & $42.1 \pm 6.1$ & 0.76 \\
\hline STAI-State score (Post-information)" & $39.1 \pm 4.7$ & $41.5 \pm 4.9$ & 0.02 \\
\hline HADS anxiety (Pre-information)" & $11.7 \pm 2.4$ & $11.5 \pm 2.4$ & 0.62 \\
\hline HADS anxiety (Post-information)" & $9.7 \pm 2.2$ & $10.9 \pm 2.4$ & 0.01 \\
\hline VAS scores during bıopsy & $2(1-2)$ & $2(1-3)$ & 0.20 \\
\hline Satisfaction after bıopsy & $5(4-5)$ & $4(2-4)$ & 0.001 \\
\hline \multicolumn{4}{|c|}{$\begin{array}{l}\text { "mean } \pm \text { SD, + Median and } 25-75 \text { percentiles, STAl, state-trait anxiety inventory; HADS: Hospital } \\
\text { Anxiety and Depression Scale;VAS, visual analogue scale }\end{array}$} \\
\hline \multicolumn{4}{|c|}{$\begin{array}{l}\text { Table2. Assessment of anxiety scores by educational st } \\
\text { Level of education }\end{array}$} \\
\hline & $\underset{n=65}{\leq \text { High school }} \geq$ & $\begin{array}{c}\geq \text { University } \\
n=19\end{array}$ & P-value \\
\hline $\begin{array}{l}\text { STAI-State score" } \\
\text { (Pre-information) }\end{array}$ & $42.4(4.8)$ & $41.6(8.7)$ & 0.58 \\
\hline $\begin{array}{l}\text { STAI-State score } \\
\text { (Post-information) }\end{array}$ & $39.9(4.8)$ & $41.5(5.4)$ & 0.23 \\
\hline $\begin{array}{l}\text { HADS anxiety" } \\
\text { (Pre-information) }\end{array}$ & $11.6 \pm 2.1$ & $11.4 \pm 3.3$ & 0.67 \\
\hline $\begin{array}{l}\text { HADS anxiety" } \\
\text { (Post-information) }\end{array}$ & $10.3 \pm 2.3$ & $10.3 \pm 2.9$ & 0.95 \\
\hline
\end{tabular}


Table 3. Changes of STAI-S and HADS scores with information in video and no video

\begin{tabular}{|c|c|c|c|c|c|c|}
\hline Group & $\begin{array}{l}\text { STAI state anxiety } \\
\text { (Pre-information) }\end{array}$ & $\begin{array}{l}\text { STAI state anxiety } \\
\text { (Post-information) }\end{array}$ & p-value & $\begin{array}{c}\text { HADS anxiety } \\
\text { (Pre-information) }\end{array}$ & $\begin{array}{c}\text { HADS anxiety } \\
\text { (Post-information) }\end{array}$ & p-value \\
\hline Video & $42.4 \pm 5.6$ & $39.1 \pm 4.7$ & $<0.001$ & $11.7 \pm 2.4$ & $9.7 \pm 2.2$ & $<0.001$ \\
\hline
\end{tabular}

\section{DISCUSSION}

It has been noted in the literature that many of the invasive diagnostic methods give rise to concern and fear in patients, which causes anxiety in individuals. ${ }^{[3,4]}$ It is therefore stated that informing patients is essential. ${ }^{[5]}$ It is important that information be simple, understandable, reduce anxiety, and not take much time. In the present study, we investigated the effect of video information on patient anxiety before endometrial biopsy. To the best of our knowledge, this is the first study to assess the effect of video information on anxiety before endometrial biopsy. Our findings showed that video information is effective in reducing anxiety levels, but written/ verbal information did not alter anxiety levels. While there was no significant difference between the two groups in terms of VAS scores, satisfaction level was higher in the group that received video information.

Previous studies on the impact of video information on anxiety have reported contradictory results. In the literature, it was reported that providing video information to patients before surgeries such as colonoscopy and cardiac catheterization increases patient comfort and reduces stress. ${ }^{[1,15]}$ Jlala et al. ${ }^{[7]}$ showed a decrease in anxiety levels when patients were visually informed by video. Coversely, some studies have shown that video information does not influence anxiety levels. ${ }^{[16,18]}$ Kazancıoğlu et al. ${ }^{[19]}$ reported that preoperative video information prior to dental surgery increased the anxiety level of patients. In the present study, pre-information STAI-S and HADS-A scores were high in both groups (STAI-S $\geq 42$ and HADS-A $\geq 11$ ). We did not find any significant difference between the groups in terms of pre-information STAI-S and HADS-A scores. We found that post-information STAI-S and HADS-A scores were lower in patients receiving video information in comparison with those receiving written/ verbal information.

Some studies have reported that anxiety increases along with an increase in the level of education, ${ }^{[20]}$ whereas other studies have reported that educational status has no effect on anxiety level..$^{[21]}$ Caumo et al.$^{[20]}$ reported that preoperative anxiety levels were higher in people with an education of 12 years or more. In contrast, Turhan et al. ${ }^{[22]}$ reported that there was no relationship between anxiety and education level. Studies have also reported that patients with less education have higher anxiety levels. ${ }^{[23]}$ In the present study, there was no statistically significant difference in anxiety with respect to educational status.
Studies have shown that state anxiety elevation is effective in increased pain intensity and reduction of pain tolerance in patients. ${ }^{[24]}$ Sağır et al. ${ }^{[25]}$ reported that preoperative visual information method reduces postoperative pain and the use of analgesics. Similarly, Kain et al. ${ }^{[26]}$ found a positive correlation between preoperative stress and pain. Unlike these studies, we did not find a statistically significant difference between the groups in terms of VAS scores. We found no significant decrease in VAS scores despite a significant reduction in anxiety levels in patients receiving video information.

Usually, for invasive or non-invasive procedures, information is provided to patients in the form of written, verbal, or video content. There is no consensus on how to provide complete and effective information and which method patients are more satisfied with. In the present study, satisfaction was higher in the group receiving video information and a significant difference was found between the groups. This result indicates that video information increases patient satisfaction.

There are certain limitations in this study. Firstly, we did not specifically measure the previous knowledge of the patients participating in the study regarding endometrial biopsy. With the ease of access to medical information, most people conduct preliminary research on the disease before referring to a physician. This may have influenced the patients' anxiety level. Secondly, we did not investigate whether the information provided before the procedure was understood by the patients.

\section{CONCLUSION}

We found that patients had high anxiety levels prior to endometrial biopsy. Based on the results of this study, it was determined that standard verbal and written information is not sufficient for reducing patient anxiety and does not satisfy the requirements. We believe that the implementation of distinct informative approaches may be important for reducing patient anxiety.

\section{ETHICAL DECLARATIONS}

Ethics Comittee Approval: This study protocol was approved by Clinical Research Ethical Committee of of the Faculty of Medicine of Ahi Evran University with a protocol number of 2019-12/139 and conducted in accordance with the Declaration of Helsinki and Good Clinical Practices.. 
Conflict of Interest Statement: No conflict of interest was declared by the authors.

Financial Disclosure: The authors declared that this study has received no financial support.

\section{REFERENCES}

1. Kazandi M, Okmen F, Ergenoglu AM, et al. Comparison of the success of histopathological diagnosis with dilatation-curettage and Pipelle endometrial sampling. J Obstet Gynaecol 2012;32(8):790-4.

2. Dogan E, Celiloglu M, Sarihan E, Demir A. Anesthetic effect of intrauterine lidocaine plus naproxen sodium in endometrial biopsy.Obstet Gynecol 2004;103(2):347-51.

3. Dönmez S. Dağ H. Kazandı M. Amniyosentez Öncesi Gebelerde Anksiyete ve Depresyon Risk Düzeylerinin Belirlenmesi. Acıbadem Üniversitesi Sağlık Bilimleri Derg 2012; 3(4):255-261.

4. Kinci MF, Yeşilçınar I, Acavut G, Karaşahin KE. The opinions and thoughts of women who underwent hysterosalpingography for the first time: Letter to the editor. J Turk Ger Gynecol Assoc 2018; 19(3): 169-170.

5. Ekiz S,Göz F. Koroner anjiografi öncesi hastaları bilgilendirmenin anksiyete düzeyi üzerine etkisinin değerlendirilmesi. Atatürk Üniv. Hemşirelik Yüksekokulu Derg 2005;8(1): 20-30.

6. Lin SY, Huang HA, Lin SC, Huang YT, Wang KY, Shi HY. The effect of an anaesthetic patient information video on perioperative anxiety: A randomised study. Eur J Anaesthesiol 2016;33(2):134-139.

7. Jlala HA, French LJ, Foxall GL, Hardman JG, Bedforth NM. Effect of preoperative multimedia information on perioperative anxiety in patients undergoing procedures under regional anaesthesia. Br J Anaesth 2010;104(3)369-74.

8. Wouters $T$, Soomers J, Smink M, et al. The effect of an animation video on consultation time, anxiety and satisfaction in women with abnormal cervical cytology: Animation video reduces colposcopy time. Prev Med Rep.2019;13:238-243.

9. Spielberger CD, Gorsuch RL, Lushene RE, Vagg PR, Jacobs GA. Manual for the State-Trait Anxiety Inventory (FormY) ("Self-Evaluation Questionnaire"). Palo Alto CA, Consulting Psychologists Press, 1983

10. Oner N, Le-Compte A. Handbook of the Stait-Trait Anxiety Inventory [in Turkish]. 2nd ed. Istanbul: Bogazici University Press; 1985.

11.Zigmond AS, Snaith RP. The hospital anxiety and depression scale. Acta Psychiatr Scand 1983;67:361-70.

12. Aydemir Ö, Güvenir T, Küey L, Kültür S. Hastane Anksiyete ve Depresyon Ölçeği Türkçe Formunun Geçerlik Güvenilirlik Çalışması. Türk Psikiyatri Dergisi 1997;8(4):280-7.

13. Tou $S$, Tou $W$, Mah $D$, Karatassas $A$, Hewett P. Effect of preoperative two-dimensional animation information on perioperative anxiety and knowledge retention in patients undergoing bowel surgery: a randomized pilot study. Colorectal Dis. 2013;15(5):e256-65.

14. Bytzer P, Lindeberg B. Impact of an information video before colonoscopy on patient satisfaction and anxiety - a randomized trial. Endoscopy. 2007;39(8):710-4.

15. Herrmann KS, Kreuzer H. A randomized prospective study on anxiety reduction by preparatory disclosure with and without video film show about a planned heart catheterization. Eur Heart J Eur Heart J. 1989;10(8):753-7.

16. Ketelaars PJW, Buskes MHM, Bosgraaf RP, et al. The effect of video information on anxiety levels in women attending colposcopy: a randomized controlled trial. Acta Oncol. 2017;56(12):1728-1733.

17. Byrom J, Clarke T, Neale J, et al. Can pre-colposcopy sessions reduce anxiety at the time of colposcopy? A prospective randomised study. J Obstet Gynaecol. 2002;22(4):415-20.

18. Wouters $T$, Soomers J, Smink $M$, et al. The effect of an animation video on consultation time, anxiety and satisfaction in women with abnormal cervical cytology: Animation video reduces colposcopy time. Prev Med Rep. 2019;13:238-43.
19. Kazancioglu HO, Tek M, Ezirganli S, Demirtas N. Does watching a video on third molar surgery increase patients' anxiety level? Oral Surg Oral Med Oral Pathol Oral Radiol. 2015;119(3):272-7

20. Caumo W, Schmidt AP, Schneider CN, et al. Risk factors for preoperative anxiety in adults. Acta Anaesthesiol Scand. 2001;45(3):298-307.

21. Domar AD, Everett LL, Keller MG. Preoperative anxiety: Is it a predictable entity? Anesth Analg 1989; 69: 763-7.

22. Turhan Y, Avcı R, Özcengiz D. Elektif Cerrahi Hazırlığında Preoperatif ve Postoperatif Anksiyetenin Hasta Memnuniyeti ile Illişkisi. Anestezi Dergisi 2012;20(1): 27-33

23. Kale A, Kale E, Erdemlioğlu M, Akdeniz N, Canoruç N, Yayla M. The effect of general and spinal anaesthesia on maternal and newborn cortisol levels in elective cesarean deliveries. J Perinatol 2006; 14(3):117-54.

24. Doering BG. Postoperatif Ağrı ve Psikolojik Faktörler. Doktor Derg 2009; 51: 94-6.

25. G Sağır, M Kaya, HE Eskiçırak, Ö Kapusuz, AN Kadıoğulları. Spinal Anestezi Planlanan Hastalarda Görsel Bilgilendirmenin Preoperatif Anksiyete Üzerine Etkisi. Turk J Anesth Reanim 2012; 40(5): 274-8

26. Kain ZN, Sevarino F, Alexander GM, Pincus S, Mayes LC. Preoperative anxiety and postoperative pain in women undergoing hysterectomy. A repeated-measures design. J Psychosom Res. 2000;49(6):417-22 